\title{
Mitigating Against Conflicts in the Kenyan Mining Cycle: Identification of Gaps in the Participation and Recourse for Rights Holders (Civil Society \& Community)
}

\author{
Seroni Anyona ${ }^{1, *}$, Bernard Rop ${ }^{1}$ \\ ${ }^{1}$ Jomo Kenyatta University of Agriculture \& Technology, Mining, Materials \& Petroleum \\ Engineering Department, P.O. Box 62000 - 00200, Nairobi, Kenya
}

\begin{abstract}
One of the major obstacles to sustainable development of the mining sector in Africa is conflicts. These conflicts emanate from various sources. However one of the key sources of misunderstanding is lack of communication between the rights holders (community and duty bearers (government and corporate) and this breakdown of communication is due to poor or nonexistent mechanisms of involvement of affected communities in decision making and ignorance. This study sought to examine the Kenyan Mining cycle and identify procedural and systemic gaps that if not addressed could trigger conflict in the emerging mining sector and suggest ways of mitigating them. Key among the greatest barriers to communal participation is ignorance regarding mining activities and also the language of instruction. Most rural people are uneducated and yet a large number of communication and notices are in English. Poor management of expectations is also a critical source of misunderstanding and hence conflict. Poor communal organization and lack of some sort of recognized authority give room for disorder and hence poor channels of communication.
\end{abstract}

\section{Introduction}

The management of extractive industries is one of the most critical challenges facing many resource-dependent developing countries today. Rather than stimulating broad-based economic development, reliance on resource extraction has tended to concentrate wealth and power in the hands of a few, exacerbate corruption and inequalities, lead to environmental degradation and pollution, while doing little to reduce poverty, economic disparities and generate employment. Worse still, in many countries extractive resources have fuelled violent conflicts. The recent announcement of oil discovery and other minerals has propelled Kenya as a new player in the global market for hydrocarbons and valued minerals. The International Monetary Fund (IMF) projects that oil production in Kenya is

\footnotetext{
*Corresponding author: sanyona@jkuat.ac.ke
} 
expected to start in two to three years from now, giving the country time to prepare to manage its endowment to achieve its development goals as stipulated in the 2030 Vision.

Kenya is well endowed with bulk mineral resources, some of which are already being exploited by private companies and some are yet to be prospected and exploited.

\section{Material and Method}

Kenya enacted a new law in 2016 to reinvigorate the mining sector. The new Act seeks to provide clear guidance on mining activities in Kenya. It introduces amongst other things legalization of Artisanal Miners and Transparency and Accountability through use of the Online Mining Cadastre portal for licensing and for management of mineral rights and permits. It also introduces Community Development Agreements, mandatory for all holders of large scale mining rights, and sharing of royalties among the national government, the county governments and the local communities.

The Act is intended to streamline the country's mining sector and open the gates for its development as well as ensure environmental conservation and sustainable development in the mining sector. It also seeks to address the key gaps in the Mining Act of 1940, and align the sector to the latest global trends such as value-addition and the use of technology to spur investor interest. The Cabinet Secretary for Mining has termed the Act as one of the most "progressive mining laws in the continent." (Oraro \& Co. Advocates).

From a human rights based perspective the new Act introduces major changes in how communities (rights holders) will be engaged in the mining cycle and licensing process.

\subsection{Considered Factors}

\subsubsection{Community Development Agreement}

The Act makes it mandatory for a holder of a large scale mining licence to enter into an agreement with the community where the mining operations will be carried out. This agreement is known as the Community Development Agreement

\subsubsection{Employment and Training}

The Act seeks to ensure employment opportunities are created for Kenyans, ensure skills transfer and capacity building for the citizens. Section 46 thereof provides that each mineral right holder is required to submit to the Cabinet Secretary, a program detailing how it shall recruit and train Kenyans. Furthermore, the holder of a mineral right is required to give preference to members of the community and Kenyan citizens when it comes to employment and only engage non-citizen technical experts in accordance with such local standards for registration as may be prescribed in the relevant law.

\subsubsection{Local Equity Participation}

The Act protects local participation with provisions for equity participation in large mining operations. The Act also provides for the prioritization of local procurement of goods, services and workforce. 


\subsubsection{Land Use, Water Rights Laws and Pollution}

A holder of a mineral right is also required to comply with the prevailing laws on water rights and use the land in accordance with the terms of the permit of licence. In doing so, the holder of the permit or licence will ensure that the land is used in a sustainable manner. Section 179 of the Act which deals with land use requires the holder of a permit or mining licence to ensure the sustainable use of land through restoration of abandoned mines and quarries; that the seepage of toxic waste into streams, rivers, lakes and wetlands is avoided and that disposal of any toxic waste is done in the approved areas only; that blasting and all works that cause massive vibration are properly carried out and muffled to keep such vibrations and blasts to reasonable and permissible levels in conformity with the Environmental Management and Coordination Act, (Cap. 387); and that upon completion of prospecting or mining, the land in question shall be restored to its original status or to an acceptable and reasonable condition as close as possible to its original state.

\subsubsection{Health and Safety}

The Act has provisions to ensure the health and safety of persons working at the mines. It provides that the holder of a mineral right will comply with the Occupational Health and Safety Act, 2007 with regards to the safety of workers and mine operations.

\subsubsection{Revenue Sharing}

The Act makes provision for the sharing of the royalties that are payable under the Act. Section 183(5) provides that the National Government will be entitled to 70\%, the County Government $20 \%$ and the community where the mining operations occur will be entitled to $10 \%$ of the revenue. This provision has been viewed as being probably one of the most progressive provisions in the Act, if not the environmental provisions. It embodies the spirit of the Constitution that requires equitable distribution of revenue among the national and county governments and inclusion, more so, financial inclusion for the people of Kenya.

\subsubsection{Dispute Resolution}

Section 154 of the Act provides for dispute resolution. It provides that any dispute arising as a result of a mineral right issued under the Act, may be determined by the Cabinet Secretary, through a mediation or arbitration process as may be agreed upon by the disputing parties or as may be stated in an agreement; or through a court of competent jurisdiction. Section 155 sets out the disputes that may be determined by the Cabinet Secretary.

\subsubsection{International Best Practice on Mining}

The Act generally prescribes for the carrying out of prospecting and mining activities in accordance with international best practice. Below is a discussion on some of the international best practices on mining.

\subsubsection{Sustainable Development in Mining}

Sustainable development is at the heart of international best practice on mining. There is no universally adopted definition of sustainability in the mining industry. However, there are five (5) main pillars that embody sustainable mining practices. These are Economy, Safety, 
Resource efficiency, Environment and Community. A brief description of each dimension follows.

\subsubsection{Environmental Management}

Environmental assessment is a process that will ensure the mineral right holder considers the potential environmental effects before they can begin the mining process. It is important that the impact to the environment is managed through specialized low impact exploration practices, water management, pollution prevention and control and the rehabilitation of mines after closure. The Act has several very progressive provisions on environmental management, which include the requirement for a person to obtain an impact assessment licence before being granted a mining licence. The Act also requires the holder of a mineral right to comply with the prevailing laws on water and use the land in a sustainable manner.

The Act has enhanced the provisions on the environment, health and safety. Section 176(1) states that a mineral right or other licence or permit granted under the Act shall not exempt a person from complying with any law concerning the protection of the environment. Section 176(2) further provides that a mining licence shall not be granted to a person under this Act unless the person has obtained an Environmental Impact Assessment licence, social heritage assessment and the environmental management plan has been approved. After completion of the prospecting or mining, the mineral right holder will ensure that the land in question is restored to its original status or to an acceptable or reasonable condition as close as possible to its original state.

\section{Results and Discussion}

For the management of the mining sector, the most significant human rights impacts, risks, and opportunities arise through the use of their products and services instead of their operations. This sector whose products and services present risks and/or opportunities to users or other rights holders, consideration of service (product)-level HRIAs is critical. A service (product)-level assessment identifies human rights impacts of products that can be used for beneficial purposes but can also be misused in a way that infringes on human rights(Institute for Human Rights and Business and Global Business Initiative, "State of Play: The Corporate Responsibility to Respect Human Rights in Business Relationships

\section{Conclusions}

After a thorough examination of the Kenyan mining cycle a number of gaps have been identified that if sealed will enable the sector to sustainably contribute to the development of the country. The major procedural challenges that inhibit the full participation of affected communities in decision making include:

- notices are published in the media which most $\mathrm{n}$ people may not have access to; English language used is not familiar to the larger section of the uneducated population

- Experience shows that the public participation in ESIA's is limited and normally skewed towards duty bearers

- Over centralizing decision making power in the position of the Cabinet secretary may lead to abuse of power.

- Ignorance on the part of the public regarding the mining sector and mining cycle may lead to exploitation and conflicts

- Community could be involved at the time the holder decides to surrender part of the prospecting licenced area that does not show potential for mineralization 
- the environmental protection bond is paid once in the entire life of the mining cycle This may not be sufficient to reclaim the mined areas after many years of mining

- The ESIA and ESMP are very technical documents for the uneducated population to comprehend

- No clear guidelines on compensation for land and other assets- the actual value of the land is left to concerned parties to decide

- Most local people are unskilled in complex negotiations dealing with compensation and resettlement with large multinational companies. This can lead to possible exploitation of unexposed communities

- Lack of understanding regarding the true value of land and dynamics and mining economics could lead to unrealistic expectations that often result in conflicts

- No clear regulations to identify and weed out land speculators

- No well elaborated dispute resolution system

- No clear and specific emphasis on safety for employees at the work place. This is hidden under the ESIA report which may not be standardized nor closely evaluated

- Solely depending on a statement, of attestation of no mining Act Offence Penal conviction of the applicant may not be sufficient to effectively capture the background criminal record or transparency check of the applicant

- Under these regulations the affected community or the public in general has no access to the monthly, quarterly and annual reports on mine development and mineral production

- There is no clear definition of the community where the mining operation occurs or the organizational structure to which $10 \%$ of the loyalties payable shall be entrusted. (Should it be based on clan or tribe or based on distance from the mining operation?)

- While there is a litany of regulations on mining there is little focus in Mineral Processing leaving a yawning gap that could be abused

\section{References}

1. Khalid Salim - Mining Act, 2014 Of Kenya-An Overview

2. Evans Khamala Masachi - Implications Of The Old Mining Law Cap. 306 And The Proposed Mining Act - Presentation December 2014

3. Bawa Ibrahim - Minerals Commission, Managing Africa's Resources Sustainably: Challenges of Small Scale Mining in Ghana.

4. Bridges, C.R. Gems \& Gemology, Summer, 290 (1974)

5. Butler, J., Gender Trouble: Feminism and the Subversion of Identity (Routledge, 1990)

6. Çagatay N., Trade, Gender and Poverty, UN Development Programme, (2001)

7. Dreschler, B., Small Scale Mining and Sustainable Development within the SADC Region (Mining, Minerals and Sustainable Development, IIED, London 2002)

8. http://commdev.org/files/1798_file_asm_southern_Taita Taveta County (TTC).pdf.

9. Gueye D. Mining, Minerals and Sustainable Development, 73 (2001)

10. Hentschel T., Hruschel F. and Priester M., Artisanal and Small Scale Mining: Challenges and Opportunities (International Institute for Environment and Development and WBCD, London 2003)

11. Hinton, J., CASM, an integrated Review for Development Planning (2003)

12. Hinton J.J. et al., Journal of Cleaner production 11:99, 115 (2003)

13. Hinton J., Veiga M.M. and Veiga A.T.C., Journal of Cleaner Production, 11, 99 (2003)

14. IGF, (2010) A mining policy framework; Mining and Sustainable Development 